\title{
Economic impact of digital dermatitis treatment on a dairy farm: an application of the break-even analysis
}

\section{Ibrahim Akin ${ }^{*}$ Tugba Akin ${ }^{2} \cdot$}

${ }^{1}$ Department of Surgery, Faculty of Veterinerian Medicine, Aydin Adnan Menderes University, 09100, Isikli, Aydin, Turkey. E-mail: ibraak@adu.edu.tr. "Corresponding author.

${ }^{2}$ Department of Econometrics, Faculty of Aydin Economics, Aydin Adnan Menderes University, Aydin, Turkey.

\begin{abstract}
This study aimed to evaluate the economic efficiency of DD treatment on milk yield in lame cows suffering from DD. A total of 33 Holstein dairy cows with DD were included in the study. The milk yields were assessed as (1st); beginning milk production (BMP), $\left(2^{n d}\right)$; peak milk production before the diagnosis (PMPBD), $\left(3^{\text {rd }}\right)$; diagnosis day milk production (DMP), and (4th); post-treatment milk production (TMP). In the first stage of analyses, using the E-views equity test of means program, cows were classified into three groups for diagnosis time of DD according to the day in milk (DIM) (Group 1: $0 \leq D I M \leq 50$, Group 2: $51 \leq D I M \leq 100$, and Group 3: $101 \leq D I M \leq 150$ ). Analysis of variance (ANOVA F-Test) and the Welch F-Test were conducted to compare the means of TMP to BMP, PMPBD, and DMP. Differences between TMP and DMP were statistically significant in all three groups. In the second stage of analyses, a cost-benefit analysis was conducted to determine the break-even point for each group to cover treatment costs for increasing milk yield. The DIM of DMP was considered as the gained milk yield per cow. Treatment cost and the mean break-even DIM for each group was then calculated. After treatment, the mean optimum break-even day for Groups 1, 2, and 3 was determined as 18.68,26.43, and 27.14, respectively. Results suggested that treatment of DD may be considered as favorable and useful for a dairy economy.
\end{abstract}

Key words: dairy cow, digital dermatitis, treatment, dairy economics, break-even analysis.

O impacto econômico do tratamento da dermatite digital em uma fazenda leiteira: a aplicação da análise do ponto de equilíbrio econômico

RESUMO: Esse estudo tem o objetivo de avaliar a eficiência econômica no tratamento da DD na produção de leite em vacas tratadas com claudicao. Foram incluidas no total 33 vacas leiteiras Holstein com DD nesse estudo. A produção de leite foi avaliada $\left(1^{\circ}\right)$; início da produção de leite $(B M P), 2^{\circ}$; pico na produção de leite antes do diagnostico (PMPBD), $\left(3^{\circ}\right)$; dia de diagnostico da produção de leite $(D M P)$, e $\left(4^{\circ}\right)$; produção de leite pós-tratamento (TMP). Na primeira etapa das análises, utilizamos o programa E-views Equity Test of Mean, as vacas foram classificadas em três grupos para o tempo de diagnostico de DD Segundo o dia do leite (DMI) (Grupo 1:0 $\leq$ DIM $\leq 50$, Grupo $2: 51 \leq$ DIM $\leq$ 100 e Grupo 3: $101 \leq D I M \leq 150$ ). A análise de variância (ANOVA F-Test) e o Welch F-Test foram conduzidos para comparar as medias de TMP a BMP, PMPBD e DMP. Diferenças entre TMP e DMP foram estatisticamente significativas nos três grupos. No segundo estágio das análises, uma análise de custo-beneficio foi realizada para determinar o ponto de equilibrio para cada grupo para cobrir os custos de tratamento e aumentar a produção de leite. O DIM de DMP foi considerado como a produção de leite adquirida por vaca. O custo do tratamento e o DIM médio de equilibrio para cada grupo foram então calculados. Após o tratamento, o dia de equilibrio ideal médio para os Grupos 1, 2 e 3 foi determinado como 18,68; 26,43 e 27,14, respectivamente. Os resultados sugerem que o tratamento de DD pode ser considerado favorável e útil para uma economia leiteira.

Palavras-chave: vaca leiteira, dermatite digital, tratamento, economia leiteira, análise break-even.

\section{INTRODUCTION}

Prevention of lameness on dairy farms is important for both animal welfare and economic loss concerns. Digital dermatitis (DD) is one of the main reasons for lameness in dairy cows. Several options (e.g. vaccination, footbath and antibiotic application) have been reported for preventing and treatment of DD. However, these options are controversial due to some potential drawbacks; (1) Vaccination against DD has been considered as weak and inconsistent (PALMER \& O'CONNEL, 2015). (2) Footbaths have commonly been used to treat DD in herds, but strict guidelines for treatment are necessary to 
avoid environmental waste and DD contamination. (3) Systemic or local antibiotic applications are also recommended for individual DD treatment (BODIL et al., 2009; YANO et al., 2010; APLEY, 2015). However, only local applications are preferred to avoid residue problem in the milk. In addition, the local applications are high-priced and timeconsuming. Therefore, single treatment is used for animal welfare, decreasing culling, and elimination of the explicit source of DD.

In cows with DD, decreased milk yield is an important economic issue (BRUIJNIS et al., 2010); although it does not always result in a reduction in milk (PALMER \& O'CONNEL, 2015). Conversely, it has been reported that there is significant increase in the milk yield after dairy cows with reduced milk yield healed with a suitable treatment against DD (AMORY et al., 2008). Single individual treatment for DD tends to be considered as an extra economic burden in the dairy economy. Despite some therapeutic applications as discussed above, a single intervention for DD is still needed to compensate the treatment cost by increasing milk yield. In this respect, this study also aimed to evaluate the economic efficiency of a single treatment for DD in the context of increasing milk yield due to the treatment in lame dairy cows.

\section{MATERIALS AND METHODS}

\section{Animals and housing}

From September 2015 to June 2016, a total of 33 Holstein dairy cows (aged from 3 to 5 years old and up to $550 \mathrm{~kg}$ in weight) with lameness due to DD were included in the study from a commercial dairy herd (the average number of dairy cows are 550) in Aydin, Turkey. The animals were housed in a freestall, mattress-based barn with automatically scraped concrete floors, and they were fed with a total mixed ration (TMR). Cows were milked three times a day with a Duovac TM milking machine (Alfa Laval Agri, $\mathrm{SE}$ ). According to the owner's information, cows had been subjected to footbath by applying copper sulfate (CuSO4) in a non-regular basis (up to twice during the entire winter). The owner stated that the farm manager and veterinarian occasionally decided whether footbath was necessary. The lameness score (LS) was calculated as previously described by SPRECHER et al. (1997). Only cows with LS $\geq 3$ were included in the study. In this study, the selected cows had exclusively DD. They did not have any other concomitant foot diseases. DD lesions were not scored, but all were ulcerative and active lesions with a mild pain during palpation.

\section{Treatment}

To treat cows with DD, individual bandages (modified from PIJL, 2003) were used as an acceptable treatment protocol. This method has previously been shown to be reliable as demonstrated by the fact that lesions were drastically healed (AKIN et al., 2013; AKIN et al., 2015). Until DD lesions were healed, the combination of amoxicillin and clavulanic acid was topically applied over the lesions with individual bandages, which were changed weekly after the morning milking. Until end of the treatment, cows were kept in the same conditions in terms of management (housing, feeding etc.). Lameness absence, no pain during palpation, and full epithelialization were observed in the cows with healed lesions.

\section{Statistical and economic analyses}

The analyses were performed in two stages. In the first stage, cows were categorized into three groups based on the DD diagnosis time (the day in milk [DIM]) according to the E-views equity test of means program: Group 1: $0 \leq \mathrm{DIM} \leq 50$, Group 2: $51 \leq$ DIM $\leq 100$, and Group 3: $101 \leq \mathrm{DIM} \leq 150$ ). The data for the milk yields were collected from computer records and categorized as four stages: (1) beginning of milk production (lactation) (BMP), (2) peak milk production before diagnosis day (PMPBD), (3) milk production on the diagnosis day (DMP, at the beginning of the treatment), and (4) post-treatment milk production (TMP, at the end of the treatment).

The treatment effect on the milk yield was compared using two different equity tests of means according to what period cows were in. One of them was the ANOVA F-Test (one-way ANOVA), which provides a single and simultaneous comparison of the series with an equality analysis method of the mean between two series. In one-way ANOVA, the F-Statistic is:

$F=$ variation between sample means/variation within the samples (1)

We applied the other equity test of the means for a cross-check which was the Welch F-Test, a modified F-statistic, which was considered when the variance was not equal. Overall, the ANOVA F-Test and the Welch F-Test were conducted to compare the variations (TMP, BMP, PMPBD, and DMP) and to find whether the intervention (treatment) was significant. The null hypothesis $\left(H_{o}\right)$ for the ANOVA F-Test and the Welch F-Test is that "there is no difference in the means between the series" and $H_{o}$ was accepted if $p \geq 0.05$.

In the second stage, we also used to evaluate cost-benefit analyses that were conducted 
to determine the break-even point (break-even DIM) for the cost of each group's treatment in terms of increasing milk yield. Break-even point analysis is a measurement system that calculates the margin of safety by comparing treatment cost and daily milk revenues. It is a financial method to assess serviceable financial decisions for farms (BERRY 1972; GALLIGAN et al., 1987; GALLIGAN et al., 1991; CARPENTER et al., 2007). Major benefit of the break-even analysis is that it demonstrates the lowest level of business activity which would prevent revenue loss (GUTIERREZ and DALSTED, 1990). During the healing period, treatment costs and increased milk yield revenues were compared. The analysis indicated that the duration of positive treatment for milk yield after the diagnosis day to subsidize the treatment cost. Treatment cost was obtained from farm accounting records and its details are shown in table 1 for one-week. The milk sales price per liter was taken as TL (Turkish currency) 1.10 (about 31 cents according to CBRT USD/TL rates as of 12/31/2016).

Since daily milk productivity is different each day, studies by GUTIERREZ and DALSTED (1990) were followed, and the break-even point formula was revised and calculated as below:

$\sum_{i=\rho}^{t}(X-Y)_{i} * P_{i}^{m}=\sum_{i=1}^{k} C_{i}$

Where $X$ shows milk production per cow, $Y$ is milk production on the diagnosis will be day, shows milk price, and $C$ shows overall cost of treatment. In addition, $t$ means break-even point day and $k$ connotes treatment period. The left side of the equation indicates more daily milk revenues until the break-even point day or the point at which cost per day and additional revenues were equal to each other. Rate of milk productivity growth $\left(\mathrm{PG}_{\mathrm{m}}\right)$ was calculated by using the formula below:

$\mathrm{PG}_{\mathrm{m}}=(\mathrm{TMP}-\mathrm{DMP} / \mathrm{DMP}$ (3)

\section{RESULTS}

A total of 23 cows were scored as 3 $(\mathrm{LS}=3)$ while 10 were scored as $4(\mathrm{LS}=4)$. At the end of the treatment, the lameness and pain disappeared completely and all lesions were covered with normal skin epithelia.

\section{Descriptive statistics}

The mean milk yields at the stages of BMP, PMPBD, DMP, and TMP, lactation number $(\mathrm{LN})$, treatment periods $\left(\mathrm{T}_{\mathrm{p}}\right)$, and the rate of milk productivity growth $\left(\mathrm{PG}_{\mathrm{m}}\right)$ of each group are presented in table 2. Based on this overview, cows in the first 50 days of lactation (Group 1) benefited the most by treatment $\left(\mathrm{PG}_{\mathrm{m}}=0.69 \pm 0.83\right)$. The DMP of groups was lower than BMP while TMP was similar with PMPBD in groups 2 and 3. The DIM in group 1 was higher than that of groups 2 and 3 .

Table 3 presents the mean milk yield of each period and the statistical significance of increased milk yield after treatment. According to the degrees of freedom (df) stated in the table and at a 0.05 significance level for both test results, it reported that $p \leq 0.05$ for DMP and TMP which means $H_{o}$ was rejected. Therefore, it was concluded that there was a statistically significant difference in the mean of milk yield before and after treatment. For all three groups, there was no difference between the mean of PMPBD and TMP ( $p$ $>0.05$ ), suggesting that the milk yield obtained at TMP was the similar with the milk yield obtained at PMPBD.

Table 1 - Overall cost of treatment per dairy cow.

\begin{tabular}{lcc}
\hline Items & TL Values & Dollar values (dated 12/31/2016) \\
\hline Cotton & 2 & 0.57 \\
Tourniquet & 1.6 & 0.45 \\
Vet Flex & 5 & 1.42 \\
Grey Bandage & 2.7 & 0.77 \\
Bituminous Bandage & 5.4 & 1.53 \\
Amoxicillin and clavulanic acid & 3 & 0.85 \\
Total & 19.7 & 5.59 \\
Veterinary cost per cow (Weekly) & 16.5 & 4.68 \\
\hline Overall cost of treatment & 36.2 & 10.27 \\
\hline
\end{tabular}

Source: All costs in this study were obtained from farm accounting records. ${ }^{*}$ Veterinary cost per cow (Weekly) = Salary (according to tariff of fares of The Chamber of Veterinary Surgeons, Aydin/Turkey)/average number of animals treated in a working day*). 
Table 2 - The mean milk yields (BMP, PMPBD, DMP, TMP), lactation number (LN), treatment periods $\left(\mathrm{T}_{\mathrm{p}}\right.$ ), and the rate of milk productivity growth $\left(\mathrm{PG}_{\mathrm{m}}\right)$ of groups.

\begin{tabular}{|c|c|c|c|c|c|c|c|c|c|}
\hline & & $\mathrm{n}$ & BMP & PMPBD & DMP & TMP & $\mathrm{LN}$ & $\mathrm{T}_{\mathrm{p}}$ (day) & $\mathrm{PG}_{\mathrm{m}}(\%)$ \\
\hline & 1 & 19 & $27.42 \pm 7.63$ & $31.63 \pm 9.43$ & $24.68 \pm 9.23$ & $36.16 \pm 8.08$ & $1.84 \pm 1.5$ & $20.21 \pm 10.41$ & $0.69 \pm 0.83$ \\
\hline \multirow[t]{2}{*}{ Group } & 2 & 7 & $30.71 \pm 8.77$ & $39.57 \pm 4.72$ & $30.71 \pm 2.87$ & $37.43 \pm 2.32$ & $3.14 \pm 1.35$ & $19.43 \pm 11.57$ & $0.22 \pm 0.09$ \\
\hline & 3 & 7 & $31.86 \pm 6.54$ & $38.64 \pm 7.77$ & $26.64 \pm 6.35$ & $37.43 \pm 8.56$ & $2.57 \pm 0.79$ & $21.86 \pm 5.49$ & $0.43 \pm 0.25$ \\
\hline
\end{tabular}

$\mathrm{n}$ : Number of cows.

\section{Break-even point analysis}

Duration of treatment expenses are important items which were compensated to firms in order to make a maximum profit. At the second stage, break-even point analysis was performed for the all 3 groups as the results are seen in table 4 . Treatment period $\left[\mathrm{T}_{\mathrm{p}}\right.$ (day)], total treatment cost $\left[\mathrm{T}_{\mathrm{c}}(€)\right]$, and break-even point days $\left[\mathrm{BEP}_{\mathrm{D}}\right.$ (day)] for each cow is also presented in table 4 showing that, except for 4 cows (cows 1, 3, 8, and 19) in Group 1 , early $\mathrm{BEP}_{\mathrm{D}}$ was better than $\mathrm{T}_{\mathrm{P}}$; that is, 15 cows in the groups subsidized for treatment costs took place earlier than the conclusion of $\mathrm{T}_{\mathrm{P}}$. There were 1 and 5 cows with the same situation in Groups 2 and 3, respectively. To this end, groups 1, 2, and 3 covered the treatment cost for an average of $18.68,26.43$, and 27.14 days, respectively.

\section{DISCUSSION}

To eradicate DD outbreaks on the farms, strict rules should be followed. Treatment of DD individually is the strategy to eliminate a DD outbreak. It also reduce the reservoir of DD lameness in the herd. As is well-accepted, lameness has a negative effect on animal behavior, milk production, reproductive performance, and weight gain in the affected herd.
The cows with DD have lower conception rate because of increased number of open days and intervals of calving (ARGAEZ-RODRIGUEZ et al., 1997; GOMEZ et al., 2015). Cows in this study were lame (LS $\geq 3$ ) due to DD. Except for other negative effects of lameness, only milk yield during the healing period of DD was evaluated in this study. If negative effects were examined and calculated, the break-even point would have possibly been reported earlier in all groups. This may be an issue for long-term studies.

Concurrent diseases, condition of the cattle, design and opportunities of the farm and experience of practitioner are some of influencing factors on reducing foot lesions in dairies. Cows used in this study have only DD problem, there was no concurrent (systemic or foot) disease/lesion. All DD lesions were ulcerative, active and painful. The farm was relatively big (550 dairy cows capacity) and modern in the region (Aydin, TR) and the owner, veterinarian and employees in the farm were collaborative during the study period. The lesions were treated by one of the author (IA) of the study. If above-mentioned factors were considered to be different in other dairy farms, the break-even points of DD lesions may be earlier or later depending on the conditions in the farms.

Table 3 - The importance of the increase in milk yield after treatment.

\begin{tabular}{|c|c|c|c|c|c|c|c|c|c|c|}
\hline \multirow[b]{2}{*}{ Group } & \multirow[b]{2}{*}{ Methods } & \multicolumn{3}{|c|}{-----------BMP and TMP----------- } & \multicolumn{3}{|c|}{---------PMPBD and TMP--------- } & \multicolumn{3}{|c|}{-----------DMP and TMP----------- } \\
\hline & & df & Value & $p$ & $\mathrm{df}$ & Value & $p$ & $\mathrm{df}$ & Value & $\rho$ \\
\hline \multirow[t]{2}{*}{1} & ANOVA F-Test & $(1,36)$ & 11.75 & $<0.001$ & $(1,36)$ & 2.52 & 0.12 & $(1,36)$ & 16.63 & $<0.001$ \\
\hline & Welch F-Test & $(1,35.88)$ & 11.75 & $<0.001$ & $(1,35.16)$ & 2.52 & 0.12 & $(1,35.38)$ & 16.63 & $<0.001$ \\
\hline \multirow[t]{2}{*}{2} & ANOVA F-Test & $(1,12)$ & 3.84 & 0.07 & $(1,12)$ & 1.16 & 0.30 & $(1,12)$ & 23.19 & $<0.001$ \\
\hline & Welch F-Test & $(1,6.83)$ & 3.84 & 0.09 & $(1,8.73)$ & 1.16 & 0.31 & $(1,11.49)$ & 23.19 & $<0.001$ \\
\hline \multirow[t]{2}{*}{3} & ANOVA F-Test & $(1,12)$ & 1.87 & 0.20 & $(1,12)$ & 0.08 & 0.79 & $(1,12)$ & 7.17 & 0.02 \\
\hline & Welch F-Test & $(1,11.23)$ & 1.87 & 0.20 & $(1,8.73)$ & 0.08 & 0.79 & $(1,11.07)$ & 7.17 & 0.02 \\
\hline
\end{tabular}

df: degrees of freedom; BMP: beginning day of milk production; PMPB: peak milk production before diagnosis day; DMP: diagnosis day of milk production; TMP: milk production at the end of the treatment. 
Table 4 - Break-Even point analysis for 3 Groups.

\begin{tabular}{|c|c|c|c|c|c|c|c|c|c|c|c|}
\hline Cow no & $T_{p}$ & $T_{C}$ & $B E P_{D}$ & Cow no & $T_{p}$ & $T_{C}$ & $B E P_{D}$ & Cow no & $T_{p}$ & $T_{C}$ & $B E P_{D}$ \\
\hline 1 & 7 & 36.2 & 15 & 1 & 14 & 72.4 & 22 & 1 & 25 & 129.29 & 23 \\
\hline 2 & 21 & 108.6 & 10 & 2 & 45 & 232.71 & 57 & 2 & 15 & 77.57 & 59 \\
\hline 3 & 7 & 36.2 & 9 & 3 & 14 & 72.4 & 26 & 3 & 15 & 77.57 & 19 \\
\hline 4 & 14 & 72.4 & 13 & 4 & 14 & 72.4 & 20 & 4 & 21 & 108.6 & 18 \\
\hline 5 & 14 & 72.4 & 9 & 5 & 21 & 108.6 & 32 & 5 & 28 & 144.8 & 23 \\
\hline 6 & 21 & 108.6 & 19 & 6 & 14 & 72.4 & 15 & 6 & 21 & 108.6 & 21 \\
\hline 7 & 21 & 108.6 & 20 & 7 & 14 & 72.4 & 13 & 7 & 28 & 144.8 & 27 \\
\hline 8 & 7 & 36.2 & 12 & & & & & & & & \\
\hline 9 & 40 & 206.86 & 40 & & & & & & & & \\
\hline 10 & 40 & 206.86 & 35 & & & & & & & & \\
\hline 11 & 30 & 155.14 & 27 & & & & & & & & \\
\hline 12 & 30 & 155.14 & 30 & & & & & & & & \\
\hline 13 & 21 & 108.6 & 18 & & & & & & & & \\
\hline 14 & 25 & 129.29 & 19 & & & & & & & & \\
\hline 15 & 30 & 155.14 & 23 & & & & & & & & \\
\hline 16 & 14 & 72.4 & 14 & & & & & & & & \\
\hline 17 & 14 & 72.4 & 14 & & & & & & & & \\
\hline 18 & 21 & 108.6 & 19 & & & & & & & & \\
\hline 19 & 7 & 36.2 & 9 & & & & & & & & \\
\hline \multicolumn{4}{|c|}{ Average Break-Even Day $=18.68$} & \multicolumn{4}{|c|}{ Average Break-Even Day $=26.43$} & \multicolumn{4}{|c|}{ Average Break-Even Day $=27.14$} \\
\hline
\end{tabular}

DIM: day in milk; $\mathrm{T}_{\mathrm{p}}$ : treatment period (day); $\mathrm{T}_{\mathrm{c}}$ : total treatment cost $(€)$; $\mathrm{BEP}_{\mathrm{D}}$ : break-even point days (day).

Milk and dairy products are important contributions to the human diet as milk is a source of macro- and micro-nutrients and dairy cow products play a key role for food supply. Although, conflict studies on milk yield in DD have been reported (PALMER \& O'CONNEL, 2015), positive treatment effects have also been reported in the literature (AMORY et al., 2008). Individual DD treatment in dairy cows is not preferred due to its higher cost and time-wasting. These animals predicted to play a significant role in the future food supply deserve individual care in the context of animal rights and welfare. The cows with DD are, conversely, valuable for the farm in terms of the economy as well. According to the results of this study, treatment costs were compensated with milk yield gain in 27.14 days from the DMP treatment day. Thus, DD treatment of dairy cows in the herd must be reconsidered.

Very few studies have focused on the treatment of lameness (POTTERTON et al., 2012) due to DD which is an obstinate and worldwide problem. Most studies have carried out to improve animal welfare. Although, different treatment methods (e.g. (i) systemic antibiotics, individual (ii) local antibiotic/ non-antibiotic applications, (iii) herd antibiotic/ non-antibiotic footbaths, and (iv) vaccinations) have been described (PIJL, 2003; LAVEN and LAGUE, 2006; AKIN et al., 2015; TOHOLJ et al., 2012; PALMER \& O'CONNEL, 2015). The best treatment considered for DD is to application of individual local medication (LAVEN and LAGUE, 2006) for easier healing. Similarly, it has been reported that the antibiotic application and bandages from among aforementioned five treatment options resulted in the most efficient treatment ( $86 \%$ recovery) (TOHOLJ et al., 2012). Antibiotic or non-antibiotic applications [gel (HOLZHAUER et al., 2011), cream (MOORE et al., 2001), paste (KOFLER et al., 2004; ELSHAFAEY et al., 2016), bandages (CUTLER et al., 2013), wraps (KOHLMAN and BJURSTROM, 2016), and light bandages (MANSKE et al., 2002)] have been used topically for DD treatment. Treating DD lesions with maximum efficiency at minimum cost is a common approach of these studies. Due to the accepted method in Turkey, which has been efficiently used before (AKIN et al., 2013; AKIN et al., 2015), individual bandages (modified from PIJL, 2003) were used in this study. Although, prices can vary, the bandages may have had the highest cost (\$10.27, Table 1) vs. topical application in the above- 
mentioned studies. Bandages applied in this study were used for a week and then replaced on a weekly basis. Accordingly, extended antibiotic contact on the lesion surface supplied by bandage led to full recovering in our current study. Less costly bandages with the same efficiency provided an earlier breakeven point than reported here.

Break-even analysis is beneficial for determining "sketches" of possible outcomes vs. actual outcome(s) while this information is valuable in the decision-making process. Break-even point analysis is used for different aspects of the economy (GUTIERREZ and DALSTED, 1990) such as in dairies (BERRY 1972; GALLIGAN et al., 1987; GALLIGAN et al., 1991; CARPENTER et al., 2007). However, the authors have not yet conducted a study that analyzed the efficacy of DD treatment in dairies. Given a break-even analysis, this study may determine what will likely occur in the dairy economy in terms of assuming individual DD treatment.

All cows in the present study were clinically lame ( $\mathrm{LS} \geq 3$ ) owing to DD lesions while only milk yield was studied to determine breakeven points. In addition to other negative effects of lameness, early detection and treatment of DD with using lower cost bandages may decrease the breakeven point and should definitely be examined. The milk yield achieved with TMP is an approximate milk yield reported in PMPBD, yet results are consistent with our expectations. Taken together, cows with DD, especially during the first 50 DIM, should be treated individually.

\section{ACNOWLEDGEMENTS}

All procedures, treatments, and animal care were approved by the Adnan Menderes University Institutional Animal Ethics Committee and conducted in accordance with the national and international laws and guidelines (Approval number: 2010/104 and the date approved on 09/29/2010), and informed written consent was obtained from the owner of the dairy farm prior to the study. The authors thank Arif Gürdal Dairy Farm in Aydın, TR.

\section{DECLARATION OF CONFLICTING INTERESTS}

The authors declare no conflict of interest. The founding sponsors had no role in the design of the study; in the collection, analyses, or interpretation of data; in the writing of the manuscript, and in the decision to publish the results.

\section{REFERENCES}

AKIN, I. et al. A case of complicated sole ulcer and its treatment in a calf. Kafkas Univ. Vet. Fak. Derg., v. 19 (Suppl-A): A229-A231, 2013. Available from: < http://vetdergi.kafkas.edu.tr/
extdocs/2013_A/A229-A231.pdf>. Accessed: Mar. 13, 2016. doi: $10.9775 / \mathrm{kvfd} .2012 .8378$.

AKIN, I. et al. The relationship between the histological quality of the newly formed hoof tissue and the levels of trace elements in blood serum and hoof tissues during the recovery period of some hoof diseases in dairy cows. Animal Health Prod and Hyg., v. 4(1),p. 344-349, 2015.

AMORY, J.R. et al. Associations between sole ulcer, white line disease and digital dermatitis and the milk yield of 1824 dairy cows on 30 dairy cow farms in England and Wales from February 2003-November 2004. Prev. Vet. Med., v. 83, p. 381-391, 2008. Available from: <http://dergipark.gov.tr/download/articlefile/132060>. Accessed: Mar. 13, 2016. doi: 10.3906/vet-1105-24.

APLEY, M.D. Clinical evidence for individual animal therapy for papillomatous digital dermatitis (hairy heel wart) and infectious bovine pododermatitis (foot rot). Vet. Clin. Food Anim., v. 31, p. 81-95, 2015. Available from: <https://www.ncbi.nlm.nih.gov/ pubmed/25705026>. Accessed: Mar. 13, 2016. doi: 10.1016/j. cvfa.2014.11.009.

ARGAEZ-RODRIGUEZ, F. et al. Papillomatous digital dermatitis on a commercial dairy farm in Mexicali, Mexico: Incidence and effect on reproduction and milk production. Prev. Vet. Med., v. 32, p. 275-286, 1997. Available from: <https://www.ncbi.nlm.nih.gov/ pubmed/9443334>. Accessed: Mar. 13, 2016.

BERRY, R.L. Break-even analysis: a practical tool in farm management. Am. J. Agric. Econ., v. 54.1, p. 121-125, 1972. doi: $10.2307 / 1237743$.

BODIL, H.N. et al. A study of duration of digital dermatitis lesions after treatment in a Danish dairy herd. Acta Veterinaria Scandinavica., v. 51, p. 27, 2009. Available from: <https://www. ncbi.nlm.nih.gov/pmc/articles/PMC2717074/>. Accessed: Mar. 13, 2016. doi: 10.1186/1751-0147-51-27.

BRUIJNIS, M.R. et al. Assessing economic consequences of foot disorders in dairy cattle using a dynamic stochastic simulation model. J. Dairy Sci., v. 93 (6), p. 2419-2432, 2010. Available from: $<$ https://www.ncbi.nlm.nih.gov/pubmed/20494150>. Accessed: Mar. 13, 2016. doi: 10.3168/jds.2009-2721.

CARPENTER, T. E. et al. An analysis of an early-warning system to reduce abortions in dairy cattle in Denmark incorporating both financial and epidemiologic aspects. Prev. Vet. Med., v. 78.1, p. 1-11, 2007. Available from: <http://www.sciencedirect.com/ science/article/pii/S0167587706001917>. Accessed: Mar. 13, 2016. doi: 10.1016/j.prevetmed.2006.08.002.

CUTLER, J.H. et al. 2013. Randomized clinical trial of tetracycline hydrochloride bandage and paste treatments for resolution of lesions and pain associated with digital dermatitis in dairy cattle. J. Dairy Sci., v. 96, p. 7550-7557, 2013. Available from: <https:// www.ncbi.nlm.nih.gov/pubmed/24140336>. Accessed: Mar. 13, 2016. doi: 10.3168/jds.2012-6384. Epub 2013 Oct 17.

EL-SHAFAEY, E.S. et al. 2016. Comparative therapeutic effect of antiseptic-antibiotic paste for topical treatment of digital dermatitis in dairy cows. Veterinarski arhiv., v. 86(2), p. 197-208, 2016. Available from: <https:/hrcak.srce.hr/file/230958>. Accessed: Mar. 13, 2016.

GALLIGAN, D.T. et al. Application of type i and ii errors in dairy farm management decision making1. J. Dairy Sci., v. 74.3, p. 902- 
910, 1991. Available from: <http://www.journalofdairyscience. org/article/S0022-0302(91)78239-8/abstract>. Accessed: Mar. 13, 2016. doi: 10.3168/jds.S0022-0302(91)78239-8.

GALLIGAN, D. T. et al. Economic decision making in veterinary practice: expected value and risk as dual utility scales. Prev. Vet. Med., v. 5.2, p. 79-86, 1987. Available from: < http://www. sciencedirect.com/science/article/pii/0167587787900134> Accessed: Mar. 13, 2016. doi: 10.1016/0167-5877(87)90013-4.

GOMEZ, A. et al. First-lactation performance in cows affected by digital dermatitis during the rearing period. J. Dairy Sci., v.98, p. 4487-4498, 2015. Available from: <https://www.ncbi. nlm.nih.gov/pubmed/25958279>. Accessed: Mar. 13, 2016. doi: $10.3168 /$ jds.2014-9041.

GUTIERREZ, P.H.; DALSTED, N.L. Break-even method of investment analysis. Colorado State University Cooperative Extension, 1990. Available from: <http://extension.colostate. edu/topic-areas/agriculture/break-even-method-of-investmentanalysis-3-759-2/>. Accessed: Mar. 13, 2016.

HOLZHAUER, M. et al. Curative effect of topical treatment of digital dermatitis with a gel containing activated copper and zinc chelate. Vet. Rec., v. 169, p. 555-558, 2011. Available from: <http://veterinaryrecord.bmj.com/content/ vetrec/169/21/555.full.pdf $>$. Accessed: Mar. 13, 2016. doi $10.1136 /$ vr.d5513

KOFLER, J. et al. Efficacy of the non-antibiotic paste protexinhoof-care for topical treatment of digital dermatitis in dairy cows. J. Am. Vet. Med. Assoc., v. 51, p. 447-452, 2004. Available from: $<$ https://www.ncbi.nlm.nih.gov/pubmed/15610490>. Accessed: Mar. 13, 2016. doi: 10.1111/j.1439-0442.2004.00671.x.

KOHLMAN, T.; BJURSTROM, A. Proper foot wrap application, 2016. Available from: <http://fyi.uwex.edu/dairy/files/2015/07/ proper-foot-wrap-application.pdf/>. Accessed: Mar. 13, 2016.

MANSKE, T. et al. Topical treatment of digital dermatitis associated with severe heel-horn erosion in a Swedish dairy herd. Prev. Vet. Med., v. 53, p. 215-231, 2002. Available from: $<$ http://www.sciencedirect.com/science/article/pii/ S0167587701002689?via\%3Dihub>. Accessed: Mar. 13, 2016. doi: 10.1016/S0167-5877(01)00268-9.
MOORE, D.A. et al. Efficacy of a nonantimicrobial cream administered topically for treatment of digital dermatitis in dairy cattle. J. Am. Vet. Med. Assoc., v. 219, p. 1435-1438, 2001. Available from: <http://avmajournals.avma.org/doi/abs/10.2460/ javma.2001.219.1435? journalCode=javma $>$. Accessed: Mar. 13, 2016. doi: 10.2460/javma.2001.219.1435.

PALMER, M.A.; O'CONNELL, N.E. Digital dermatitis in dairy cows: a review of risk factors and potential sources of between-animal variation in susceptibility. Animals, v. 5, p. 512-535, 2015. Available from: <https://www.ncbi.nlm.nih.gov/pmc/articles/PMC4598691/>. Accessed: Mar. 13, 2016. doi: 10.3390/ani5030369.

PIJL, R. Klauenprobleme schneller lösen. Landwirtsshaftsverlag Gmbh, Münster-Hiltrup, Germany, pp: 24-25, 2003.

POTTERTON, S.L. et al. A descriptive review of the peer and nonpeer reviewed literature on the treatment and prevention of foot lameness in cattle published between 2000 and 2011. Vet. J., v. 193, p. 612-616, 2012. Available from: <http://www.sciencedirect. com/science/article/pii/S1090023312002882?via\%3Dihub>. Accessed: Mar. 13, 2016. doi: 10.1016/j.tvj1.2012.06.040.

LAVEN, R.A.; LOGUE, D.N. Treatment strategies for digital dermatitis for the UK. The Veterinary Journal, v. 171, p. 79-88, 2012. Available from: <http://www.sciencedirect.com/science/ article/pii/S1090023304001789?via\%3Dihub>. Accessed: Mar. 13, 2016. doi: 10.1016/j.tvj1.2004.08.009.

SPRECHER, D.J. et al. A lameness scoring system that uses posture and gait to predict dairy cattle reproductive performance. Theriogenology, v. 47, p. 1178-1187, 1997. Available from: <http:// www.theriojournal.com/article/S0093-691X(97)00098-8/pdf >. Accessed: Mar. 13, 2016. doi: 10.1016/S0093-691X(97)00098-8.

TOHOLJ, B. et al. Effificiency of different therapeutic protocols in treating digital dermatitis in dairy cows. Veterinarski Arhiv., v. 82 (2), p. 133-142, 2012. Available from: <https://hrcak.srce.hr/ file/116332>. Accessed: Mar. 13, 2016.

YANO, T. et al. Antimicrobial susceptibility of treponema phagedenislike spirochetes isolated from dairy cattle with papillomatous digital dermatitis lesions in Japan. J. Vet. Med. Sci., v. 72(3), p. 379-82, 2010. Available from: <https://www.jstage.jst.go.jp/article/jvms/72/3/72 090418/_article>. Accessed: Mar. 13, 2016. doi: 10.1292/jvms.09-418. 